\title{
10-12 Yaş Okul Çocuklarında Beslenme ve Fiziksel Aktivitenin Vücut Kompozisyonu ve Uyku Kalitesine Etkisi
}

\author{
Latifa Azimova $^{1}$, Ecenur Özkul ${ }^{2}$, Can Ergün ${ }^{3 *}$ \\ ${ }^{1}$ Medera Hastanesi, Bakü, Azerbaycan, (ORCID: 0000-0003-0129-5704), latifa-azimova@mail.ru \\ ${ }^{2}$ Bahçeşehir Üniversitesi, Sağlık Bilimleri Fakültesi, Beslenme ve Diyetetik Bölümü, İstanbul, Türkiye (ORCID: 0000-0002-2651-0135), ecenur.ozkul@hes.bau.edu.tr \\ 3* Bahçeşehir Üniversitesi, Sağlık Bilimleri Fakültesi, Beslenme ve Diyetetik Bölümü, İstanbul, Türkiye (ORCID: 0000-0001-5139-4407), can.ergun@,hes.bau.edu.tr
}

(İlk Geliş Tarihi 14 Ekim 2021 ve Kabul Tarihi 30 Aralık 2021)

(DOI: 10.31590/ejosat.1009725)

\begin{abstract}
ATIF/REFERENCE: Azimova, L., Özkul, E. \& Ergün, E. (2021). 10-12 Yaş Okul Çocuklarında Beslenme ve Fiziksel Aktivitenin
\end{abstract} Vücut Kompozisyonu ve Uyku Kalitesine Etkisi. Avrupa Bilim ve Teknoloji Dergisi, (31), 943-950.

\begin{abstract}
$\ddot{O} \mathbf{z}$
Çocukluk dönemi büyüme ve gelişme açısından önemlidir. Bu dönemde kazanılan alışkanlıklar gelecekte bireyin sağlı̆̆ını etkilemektedir. Son zamanlarda yapılan çalışmalar çocukluk dönemini etkileyen faktörler arasında uyku kalitesinin büyük yer tuttuğunu vurgulamaktadır. Gelişim döneminde uyku kalitesinin düzenlenmesinin okul başarısı, vücut kompozisyonu, fiziksel aktivite ve beslenme üzerinde olumlu etkileri olabileceği savunulmaktadır. Okul çocuklarında beslenme ve fiziksel aktivitenin vücut kompozisyonu ve uyku kalitesine etkisini araştırmak amacıyla yapılan çalışma 10-12 yaş arası 300 çocuğu kapsamaktadır. Anket formu çocuk uyku alışkanlıkları anketi indeksi, sosyo-demografik özellikler, beslenme alışkanlıkları, çocuklar için fiziksel aktivite ölçeğini içermektedir. Anket sonuclarında beslenme gibi faktörlerin vücut kompoziyonunu etkilediği ve bununda uyku kalitesiyle bağlantılı olduğu bulunmuştur. Yapılan değerlendirmede genel uyku miktarı ile çocukların persentil değerleri ile anlamlı ilişki belirlenmiştir $(p<0.05)$. Karbonhidrat tüketimindeki ve enerji tüketimindeki artışların sırasıyla \%30.1, \%35.7 oranlarında uyku süresinde azalmaya neden olduğu tespit edilmiştir. $\mathrm{Bu}$ da uykunun birçok faktörle bağlantısını vurgulamakta ve sağlık üzerinde önemini vurgulamaktadır. Çalışmadan elde edilen sonuçlar literatür ile uyumlu bulunmuştur. Çocukluk çağında uykunun önemini belirlemek ve yetişkinlik döneminde oluşabilecek sağlık sorunlarını engellemek için daha fazla çalışmaya ihtiyaç vardır.
\end{abstract}

Anahtar Kelimeler: Çocuk uyku alışkanlıkları, Okulçağı beslenmesi, Çocukluk çağı obezitesi

\section{The Effect of Nutrition and Physical Activity on Body Composition and Sleep Quality in 10-12 Years Old School Children}

\begin{abstract}
Childhood is important for growth and development. The habits gained during this period affect the health of the individual in the future. Recent studies emphasize that sleep quality has a great place among the factors affecting childhood. It is argued that regulation of sleep quality during the developmental period may have positive effects on school success, body composition, physical activity and nutrition. The study, which was conducted to investigate the effects of nutrition and physical activity on body composition and sleep quality in school children, included 300 children between the ages of 10-12. The questionnaire form includes child sleep habits questionnaire index, socio-demographic characteristics, eating habits, physical activity scale for children. In the survey results, it was found that factors such as nutrition affect body composition and this is related to sleep quality. In the evaluation, a significant relationship was determined between the general amount of sleep and the percentile values of the children $(\mathrm{p}<0.05)$. At the same time, as the amount of carbohydrate consumption increases, sleep duration decreases by $30.1 \%$ and as the amount of energy increases, sleep duration decreases by $35.7 \%$. This emphasizes the connection of sleep with many factors and emphasizes its importance on health. The results obtained from the study were found to be compatible with the literature. More studies are needed to determine the importance of sleep in childhood and to prevent health problems that may occur in adulthood.
\end{abstract}

Keywords: Child sleep habits, Childhood nutrition, Childhood obesity

* Sorumlu Yazar: can.ergun@hes.bau.edu.tr 


\section{Giriş}

Diyet ve sağlıkla ilgili yaşam tarzı davranışları yaşamın erken dönemlerinde gelişmekte ve yetişkinliğe doğru ilerlemektedir. İki yaş ve altı çocuklarda gözlemlenen şişmanlığın, yetişkin dönemindeki obezite ve ilişkili hastalıklar için önemli bir belirteç olduğu bildirilmiştir (Verjans-Janssen, Van de Kolk, Van Kann, Kremers ve Gerards, 2018).

Günümüzde çocuklar yükek enerjili gıdaların tüketiminin fazla olması, düşük fiziksel aktivite ve hareketsiz bir yaşam tarzı gibi davranışları alışkanlık haline getirdiklerinden obezojenik bir ortamda büyümektedirler (Kim ve Lim, 2019). Yemek yeme davranışları incelendiğinde, Bugünün Büyümesi Araştırması (GUTS), 9 yaşındaki çocukların \%50,7'si her gün aileleriyle birlikte akşam yemeği yediğini, 14 yaşına doğru bu oranın \%35,4'e düștüğünü göstermektedir. Sağlıklı alıșkanlıkları kazandırabilmek amacıyla okul çağı çocuklarında sağlıkla ilgili davranışları kontrol etmek büyük önem taşımaktadır. Öğün düzenlemeleri ile birlikte okulda veya dier sosyal ortamlarda yanlış besin tercihi yapmak, zaman yetersizliğinden dolayı atıştırmalıklara yönelmek bu yaş grubunda çok sık yapılan hatalı davranışlardandır (Gingras, 2018).

Yeterli ve kaliteki uyku eksikliğinin çocuklar ve ergenler arasında belirtilen risk faktörlerine ek olarak obezite prevalansının artmasına katkıda bulunabileceği düşünülmektedir. Yapılan bir çalışmada, uyku kısıtlamasının seçilen endokrin sistem fonksiyonlarını olumsuz etkilediğini, iştah uyarıcı hormon ghrelin ve anoreksojenik hormon leptin seviyelerinde değişikliklere yol açtığını bildirmektedir (Kjeldsen vd., 2014). Literatürde çocukluk ve adölesan döneminde uyku bozuklukları oranlarının \%25-30 olduğu bildirilmektedir (Tolaymat ve Liu, 2017). Bir araştırmada, okul çağında çocukların 8.5-10 saat uyuması gerektiği bildirilmektedir. Yetersiz uykunun, çocuklarda sinirlilik ve dikkat eksikliğine yol açarak zayıf bir akademik performana neden olabildiği vurgulanmaktadır (Crispim vd., 2011). Uyku, fiziksel büyümenin ve akademik performansın temel bir bileşeni olarak, okul çağ 1 çocuklarında sağlığ 1 geliştirme çabalarında çok önemli bir faktördür (Den Wittenboer, 2000). Ek olarak uykunun besin seçimlerine de etki ettiği belirtilmiştir. Birbirini izleyen beş gece boyunca kronik uyku kısıtlamasının, adölesanları yüksek glisemik indeksli gıdaların tüketimine yönlendirdiği ve böylece enerji dengesizliğine yol açtığı rapor edilmiştir (Morrissey, Allender ve Strugnell, 2019). Bu nedenle, uyku yoksunluğu kilo alımını doğrudan etkilemesede, fiziksel aktivite gibi ilişkili olduğu davranış değişikliklerinin bir sonucu olarak aşırı kilo ve obezite riskini önemli ölçüde artırabilmektedir. Çocukluk dönemi alışkanlıkların kazanıldığı dönem olduğu için, bu konuda daha fazla çalışma yapılarak, mekanizmaların tekrar gözden geçirilmesi gerekmektedir. Uykunun beslenme, fiziksel aktivite gibi davranışları dolaylı yollarla etkileyerek çocukluk çağındaki öneminin vurgulanması ve yapılan yanlışların önlenmesi gerekmektedir (Harrex vd., 2017).

Yapılan çalışmada çocukluk dönemininde sağlığı etkileyebileceği düşünülen faktörlerin öneminin vurgulanması amaçlanmaktadır. Uyku düzeni, beslenme ve fiziksel aktivite alışkanlıkları bu dönem kazanıldığı için, doğru müdahele ile sağlığın temelini oluşturmak mümkündür. Çocukluk döneminde alışkanlıkların düzeltilmesi daha kalıcı ve kolay olduğu için bu dönem araştırılmalıdır.

\section{Materyal ve Metot}

\subsection{Araştırmanın Alanı ve Tarihi}

Araştırma Azerbaycan, Bakü'de bulunan QAMET ABBASOV 284 N'lı okulda okuyan 10-12 yaş grubu öğrenciler ile AğustosEkim 2019 tarihlerinde Bahçeşehir Üniversitesi 20021704-604.01 01 numaralı etik kurul izni ile tamamen gönüllülük esasına dayalı olarak yüz yüze anket yöntemiyle planlanıp yürütülmüştür.

\subsection{Anket Formu}

Araştırma verileri, ankete katılım sağlayan 10-12 yaş okul çocuklarında beslenme, fiziksel aktivite, vücut kompozisyonu ve uyku kalitesine yönelik durumlarını doğru yansıtacak şekilde hazırlanmıştır. Araştırmanın verileri toplanırken, demografik bilgiler için 8 sorudan oluşan Kişisel Bilgi Formu, 10 sorudan oluşan Çocuklar için Fiziksel Aktivite Ölçeği ve 33 sorudan oluşan Çocuk Uyku Alışkanlıkları Anketi uygulanmıştır. Ayrıca, katılımcıların 3 günlük besin tüketim kayıtları velileri tarafından kaydedilmiştir. Ek olarak, katılımcıların boy uzunluğu, üst orta kol çevresi ve vücut ağırlığı ölçülerek, vücut kütle indeksi (VKİ) hesaplanmıştır. Anketin çocuk uyku alışkanlıkları kısmı veliler aracılığ ile elde edilmiştir.

\section{3. İstatistiksel Analiz}

Araştırma kesitsel tipte bir çalışmadır. Elde edilen veriler, IBM SPSS Statistics 21.0 sürümü kullanılarak analiz edilmiştir. Çalışmada anlamlılık düzeyi $\alpha=0.05$ olarak alınmıştır. Hipotezlerin test edilmesi ve bunun için hangi testin uygun olduğunun belirlenmesi için verilerin dağılımının normal olup olmadığı sınanmıştır. Sorular normal dağılımlı olmadığı için $(\mathrm{p}<0.05)$, analizlerde normal dağ 1 lım gerektirmeyen nonparametrik yöntemler kullanılmıştır. Grup farklılı̆̆ı analizlerinde, iki grup için $t$ testi yerine non-parametrik karşılığı olan ve 2'li grup için uygunluk gösteren Mann-Whitney-U testi kullanılmıştır. İkiden fazla grup için Kruskal-Wallis testi uygulanmıştır. Besin tüketim kayd 1 verileri Beslenme Bilgi Sistemi (BEBISS) kullanılarak elde edilmiştir.

\section{Araştırma Sonuçları ve Tartışma}

Obezite, 21. yüzyılın en ciddi halk sağlığı sorunlarından biri olarak belirtilmektedir. Obezitenin oluşmasında sürekli yüksek kalorili besin alınmasının yanında pek çok faktör rol oynar. Tam olarak tanımlanmadasa genetik ve çevresel faktörler arasındaki patofizyolojinin önemli bir rol oynadığı düşünülmektedir (Hurt, Frazier, McClave ve Kaplan, 2011). Genetik faktörler arasında en önemlilerden birisi cinsiyet olarak gösterilirken, yaşanılan çevre, ebeveyn eğitim düzeyi, egzersiz seviyesi önemli çevresel faktörler arasında değerlendirilmektedir. Araştırmamızda katılımcıların yüzde 50.3'nün kız yüzde 49.7'sinin erkek olduğu belirlenmiştir. Egzersiz durumları sorgulandığında yüzde 4.3'ü hergün egzersiz yapmakta, yüzde 95,7'si ise hergün egzersiz yapmamaktadir. 


\begin{tabular}{|c|c|c|c|}
\hline \multicolumn{2}{|l|}{ Genel Bilgiler } & \multirow{2}{*}{$\begin{array}{c}\text { Kişi Sayısı (n) } \\
151 \\
\end{array}$} & \multirow{2}{*}{$\begin{array}{c}\text { Yüzde (\%) } \\
50.3 \\
\end{array}$} \\
\hline Cinsiyet & $\mathrm{K} 1 \mathrm{z}$ & & \\
\hline & Erkek & 149 & 49.7 \\
\hline \multirow{4}{*}{ Okuduğu Sınıf } & 4.sinif & 8 & 2,7 \\
\hline & 5.sinif & 77 & 25,7 \\
\hline & $6 . \sin 1 f$ & 79 & 26,3 \\
\hline & 7.snif & 136 & 45,3 \\
\hline \multirow[b]{4}{*}{ Anne eğitim durumu } & Ortaokul & 3 & 1,0 \\
\hline & Lise & 72 & 24,0 \\
\hline & Üniversite & 224 & 74,7 \\
\hline & Lisansüstü & 1 & 3 \\
\hline \multirow{4}{*}{ Baba eğitim Durumu } & Ortaokul & 0 & 0 \\
\hline & Lise & 20 & 6,7 \\
\hline & Üniversite & 271 & 90,3 \\
\hline & Lisansüstü & 9 & 3,0 \\
\hline \multirow{2}{*}{$\begin{array}{l}\text { Her gün Egzersiz } \\
\text { Yapma Durumu }\end{array}$} & Evet & 13 & 4,3 \\
\hline & Hayır & 287 & 95,7 \\
\hline
\end{tabular}

Tablo 2. Antropometrik ölçümlere yönelik tanımsal istatistikler

\begin{tabular}{l|c|c|c|c}
\hline Değişkenler & Minimum & Maksimum & Ortalama & Standart Sapma \\
\hline Vücut ă̆ırlı̆̆ı $(\mathrm{kg})$ & 21,80 & 87,00 & 40,63 & 11,52 \\
\hline Boy uzunluğu (cm) & 120,00 & 174,00 & 142,66 & 11,70 \\
\hline Üst orta kol çevresi(cm) & 14,00 & 32,00 & 21,16 & 3,01 \\
\hline VKI $\left(\mathrm{kg} / \mathrm{m}^{2}\right)$ & 11,40 & 32,80 & 19,6 & 3,63 \\
\hline
\end{tabular}

(Zhang, N. ve Ma, 2018, Christensen vd., 2016). Bizim çalışmamızda da 10-12 yaş arası 300 çocuğun (149 erkek, 151 kız) \%18'i hafif şişman, \%22.7'si ise şişman ve obez olarak belirlenmiştir (Data gösterilmemiştir.). Katılımcıların vücut

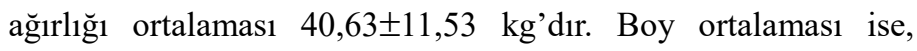

$142,66 \pm 11,71$ olarak elde edilmiştir. Üst kol çevresinin ortalamas $21,16 \pm 3,02 \mathrm{~cm}$ ve VKI ortalamas1 $19,67 \pm 3,64 \mathrm{~kg} / \mathrm{m} 2$ olarak belirlenmiştir. Bu sonuclar okul çağı çocuklarının daha fazla risk faktörlerine sahip olduklarını ve yaygınlığı doğrulamaktadır.

Tablo 3. VKİ ile anne eğitim düzeyi, sabah kahvaltı yapma ve yeterli uyuma için ilişki analizi

\begin{tabular}{l|c|c}
\hline Değişkenler & Yüzde (\%) & Pa \\
\hline Anne Eğitim Düzeyi & 5,9 &, 215 \\
\hline Sabah Kahvaltı Yapma & 17,4 &, 000 \\
\hline
\end{tabular}

Çocukluk çağı obezitesinde yüksek kalorili besin alınmasının yanı sıra öğün ve uyku saatleride önem arz etmektedir (Hurt, Frazier, McClave ve Kaplan, 2011). Kahvaltı, çocukların sağlığı, zihinsel faaliyetleri ve vücut kompozisyonu için en önemli öğün olarak nitelendirilmektedir (Ricotti vd., 2021). Beslenme veya çevresel diğer faktörlerle obeziteye sebep olacak diğer faktörler arasında çocukluk döneminde kahvaltı ögününün atlanılmasının önemli bir faktör olduğu bildirilmektedir. Başlıca sebepler kısıtlı zaman ve iştah eksikliği olarak belirtilmiştir. Ebeveyn eğitim düzeyinin özellikle beslenme alışkanlıklarında asıl belirleyici olan annenin eğitim düzeyinin yüksek olmasının çocuk ve adölesanlarda öğün düzeni üzerinde olumlu yönde etkili olduğu görülmüştür (Kartal, Burnaz, Yaşar, Sağlam ve Kıymaz, 2019) $(\mathrm{p}<0.05)$. Yapılan bir çalışmada (Akman, Tüzün ve Ünalan, 2012), anne eğitim seviyesindeki artışın çocuklarının beslenme alışkanlıklarını olumlu yönde etkilediğini dolayısıyla obezite gelişimi üzerinde etkili olabileceği bildirilmiştir. Araştırmamızda VKİ ile anne eğitim düzeyi arasında istatistik açısından anlamlı 
ilişki bulunmamaktadır ( $\mathrm{p}>0.05)$. Fakat VKİ ile sabah kahvaltı yapma değişkeni arasında istatistik açısından negatif yönlü \% 17,4 anlamlı ilişki vardır. Sabah kahvaltı yapan çocukların VKI düzeylerinin daha az olduğunu bulunmuştur.

Tablo 4. Tüketilen enerji ve besin öğelerinin antropometrik ölçümler, uyku puanı ve fiziksel aktivite puanı ilişki analizi

\begin{tabular}{|c|c|c|c|}
\hline Değişkenler & Değişkenler & Yüzde (\%) & $\mathbf{P a}$ \\
\hline \multirow{6}{*}{ Enerji } & Boy Uzunluğu & $9,9^{*}$ & 011 \\
\hline & Vücut Ağırlığ 1 & $31,3^{*}$ &, 000 \\
\hline & Üst orta kol çevresi & $38,5^{*}$ & 000 \\
\hline & VKI & $44,5^{*}$ &, 000 \\
\hline & Toplam uyku puanı & 1,7 &, 264 \\
\hline & Toplam Fiziksel Aktivite puan 1 & 25,3 &, 000 \\
\hline \multirow{6}{*}{ Karbonhidrat } & Boy Uzunluğu & 3,1 & ,423 \\
\hline & Vücut Ağırlığ1 & $20,6^{*}$ &, 000 \\
\hline & Üst orta kol çevresi & $29,6^{*}$ &, 000 \\
\hline & VKI & $33,2^{*}$ &, 000 \\
\hline & Toplam uyku puanı & 13,6 &, $000^{*}$ \\
\hline & Toplam Fiziksel Aktivite puanı & $17,8^{*}$ &, 000 \\
\hline \multirow{6}{*}{ Protein } & Boy Uzunluğu & $13,1^{*}$ &, 001 \\
\hline & Vücut Ağırlığ 1 & $25,3^{*}$ &, 000 \\
\hline & Üst orta kol çevresi & $25,9^{*}$ &, 000 \\
\hline & VKI & $30,9^{*}$ &, 000 \\
\hline & Toplam uyku puanı & 16,5 & ,453 \\
\hline & Toplam Fiziksel Aktivite puanı & $13,8^{*}$ &, 001 \\
\hline \multirow{6}{*}{ Yağ } & Boy Uzunluğu & $8,4^{*}$ &, 032 \\
\hline & Vücut Ağırlığ1 & $31,4^{*}$ &, 000 \\
\hline & Üst orta kol çevresi & $37,4^{*}$ &, 000 \\
\hline & $\mathrm{VKI}$ & $44,1^{*}$ &, 000 \\
\hline & Toplam uyku puanı & 0,1 &, 986 \\
\hline & Toplam Fiziksel Aktivite puanı & 30,2 &, 000 \\
\hline \multirow{5}{*}{ Fiziksel Aktivite } & Boy Uzunluğu & $27,6^{*}$ &, 000 \\
\hline & Vücut Ağırlığ1 & 41,5 &, 000 \\
\hline & Üst orta kol çevresi & $35,4^{*}$ &, 000 \\
\hline & VKI & 39,2 &, 000 \\
\hline & Toplam uyku puanı & 6,4 &, 123 \\
\hline \multirow[t]{5}{*}{ Uyku Puanı } & Boy Uzunluğu &, 6 &, 136 \\
\hline & Vücut Ağırlığı & $, 3,1$ & ,446 \\
\hline & Üst orta kol çevresi & $, 1,1$ &, 790 \\
\hline & VKI &, 4 &, 917 \\
\hline & Toplam Fiziksel Aktivite puan 1 & 6,4 &, 123 \\
\hline
\end{tabular}


Beslenme ve fiziksel aktiviteyi içeren yaşam tarzı değişikliği, çocukluk çağı obezitesine tedavi yaklaşımının temelini oluşturmaktadır (Ambrosini, Emmett, Northstone ve Jebb, 2014). Özellikle okul çocuklarında daha yüksek enerji, yağ, sodyum ve şeker alımının artmasının yanı sıra daha düşük meyve, sebze ve lif tüketimi görülmektedir. Yüksek enerji içeren gıda tüketiminin artması çocuklarda daha yüksek VKI ile sonuçlanmaktadır (Gingras, Hivert ve Oken, 2018). Bizim çalışmamızda persentil durumlarına göre enerji alımı incelendiğinde, çok zayıf çocuklarda enerji alımı ortalama $787 \mathrm{kcal} /$ gün olurken, hafif şişman ve şişman çocuklarda ortalama 1224- $1364 \mathrm{kcal} /$ gün olarak yükselmektedir. Ayrıca sırasıyla karbonhidrat, yağ ve protein alımı da hafif şişman ve şişman çocuklarda daha yüksek olmaktadır. VKİ değerleriyle beraber üst kol çevresi ölçümü ile de pozitif ilişkili olmaktadır. Bu da ileriki yaşlarda birçok sağlık problemini beraberinde getirebilmektedir. "Küreselleşen Dünyada Çocuklarda Büyüyen Sorun: Obezite" isimli çalışmada; şişmanlığın artmasında neden olan çevresel risk faktörleri olduğunu, çocuk ve ergenlerin yağlı ve fazla kalorili besinlere rahat ulaşımı, yüksek kalorili ve aya üstü hızlı yenen hazır besinler (fast food), lifli besin tüketiminin az olması, fast food endüstrisindeki güçlü pazarlama, fiziksel aktivitenin azlığı ve sedanter aktivitelerinin (TV izleme ve bilgisayar kullanma) artmasının da çocukluk çağı obezitesinin artmasına sebep olan diğer faktörler olduğunu belirtmektedirler (Barbaros ve Balcı, 2015). Sonuçlarımıza göre enerji oranı arttıkca boy uzunluğu yüzde 9,9 , vücut ağırlığı yüzde 31,3 , üst kol çevresi yüzde 38,5 , VKI oranı yüzde 44.5 , pozitif yönlü anlamlı ilişki göstererek artmaktadır. Enerji ile toplam fiziksel aktivite puanı ile istatistik açısından negatif yönlü yüzde 25,3 anlamlı ilişki vardır ( $p>0.05$ ).

Sadece enerji yoğun beslenme değil, aynı zamanda fiziksel aktivitenin azlığı gibi faktörlerde çocukların sağlığında risk faktörü olmaktadır. Düzenli fiziksel aktivitenin çocukların sağlığı üzerindeki olumlu etkisi bilinmektedir. Artan fiziksel aktivite, kardiyovasküler risk faktörlerindeki iyileşmelerle ilişkilendirilmektedir (Oliveira, Ferrari, Araújo ve Matsudo, 2017). Michalopoulou ve arkadaşlarının, çocuklarla yaptı̆̆ kesitsel bir çalışmada gün içerisinde atılan adımları ölçmek için pedometreleri kullanılmış ve her iki cinsiyetten normal çocukların günde aşırı kilolu olanlara göre daha fazla adım attığını bulmuştur (Michalopoulou vd., 2011). Fiziksel aktivite, toplam enerji harcamasını ve yă̆ oksidasyonunu artırarak yă̆ kütlesini azaltabilir ve yağsız vücut kitlesini koruyabilir. Bu nedenle, fiziksel aktivitenin arttırılması çocukluk çağı obezitesinin önlenmesi için önemli bir strateji olarak kabul edilmektedir (YanPing vd., 2010). Fiziksel aktivite durumunu belirlemek için kullandığımız ÇFAÖ anketininin sonuçlarına göre erkek çocuklarda toplam puan ortalama 41,59 , kız çocuklarda toplam puan ortalama 41,83 olarak belirlenmiştir. Elde ettiğimiz sonuclara göre hafif kilolu ve şişman çocuklara puan daha düşük olmaktadır. Keskin ve arkadaşlarının çalışmasında ÇFAÖ puan ortalaması 26.12 olarak bulunmuştur (Keskin, Çubuk, Alpkaya ve Öztürk, 2017). Çalışma sonuclarına göre fiziksel aktivitenin vücut kompozisyonu üzerinde etkilerine baktığımızda vücut ağıllı̆̆ ile $\% 41,5$, üst kol çevresi ile $\% 35,4$, VKİ ile \% 39,2 negatif yönlü anlamlı ilişki elde edilmişsir.

Enerji alımını artıran bir diğer faktör uyku miktarı olmaktadır. Literatürde çocukluk ve ergenlik döneminde uyku bozuklukları oranlarının \%25-30 olduğu bildirilmiş̧ir. Bir çalışmada, okul çağında çocukların ortalama 10 saat uyuması gerektiği bildirilmiştir (Sekine vd., 2002). Bir diğer çalışmada ise adölesan dönemde en az 8,5 saat uyuması gerektiğini belirtmiştir (Fisher vd., 2014). Çocuklarla yapılan en büyük pediatrik çalışmada, 8 saatten az uyuyan 6-7 yaş çocukların obez olma olasılı̆̆ının, 10 saatten fazla uyuyan çocuklardan üç kat daha fazla olduğu vurgulanmıştır (Sekine vd., 2002). Bizim yaptığımız çalışmada kullanılan CSHQ anketi sonucuna bakıldığında, ortalama erkek çocuklarda 40 puan, kız çocuklarında ise 41 puan elde edilmiştir. Toplam uyku puanında sağlık için risk oluşturmasa da, yapılan çalışmalarında desteklediği birçok faktör bizim çalışmamızda da gösterilmiştir.

Karbonhidrat ile kilo değişkeni arasında yüzde 20,6, üst kol çevresi 29,6, VKİ yüzde 33,2 pozitif yönlü anlamlı ilişki göstermektedir. Karbonhidrat ile toplam uyku puanı değişkeni arasında pozitif yönlü anlamlı ilişki vardır ve karbonhidrat değeri yükseldikçe uyku puanı yüzde 13.6 yükselmektedir. Karbonhidrat oranı arttıkca toplam fiziksel aktivite puanı yüzde 17,8 düşmektedir. Protein ile boy uzunluğu değişkeni arasında istatistik açısından yüzde 13,1 , vücut ağırlı̆̆ ile yüzde 25,2 , üst orta kol çevresi ile yüzde 25,9 , VKİ değişkeni ile yüzde 30,9 pozitif yönlü anlamlı ilişki vardır. Protein uyku puanı arasında ilişki bulunmamakta ve ile toplam fiziksel aktivite puanı ile negatif yönlü yüzde 13,8 anlamlı ilişki olmaktadır. Yağ ile boy uzunluğu değişkeni arasında istatistik açısından yüzde 8,4 , vücut ağılığı değişkeni ile yüzde 31,4, üst kol çevresi ile yüzde 37,4, VKİ değişkeni ile arasında istatistik açısından yüzde 44,1 pozitif yönlü anlamlı ilişki vardır. Yağ ile toplam uyku puanı değişkeni arasında ilişki olmamakta ve toplam fiziksel aktivite puanı değişkeni arasında istatistik açısından negatif yönlü yüzde 30,2 anlamlı ilişki olmaktadır ( $\mathrm{p}>0.05)$. Toplam fiziksel aktivite puanı ile boy uzunluğu değişkeni arasında yüzde 27,6 negatif yönlü anlamlı ilişki vardır. Toplam fiziksel aktivite puanı ile vücut ağırlığ 1 değişkeni arasında yüzde 41,5 , üst kol çevresi değişkeni ile yüzde 35,4, VKİ değişkeni ile yüzde 39,2 negatif yönlü anlamlı ilişki vardır. Toplam fiziksel aktivite puanı ile toplam uyku puanı değişkeni arasında istatistik açısından anlamlı bir iliş̧i yoktur. Uyku puanı ile antropometrik ölçümler ve fiziksel aktivite puanı arasında anlamlı ilişki elde edilmemiştir ( $\mathrm{p}>0.05)$. 
Tablo 5. Yaşa Göre Ağırlık açısından fiziksel aktivite puanı, uyku puanı ve tüketilen enerji için farklılık analizi

\begin{tabular}{|c|c|c|c|c|c|}
\hline Değişkenler & $\begin{array}{l}\text { Yaşa Göre } \\
\text { Ağırlık }\end{array}$ & $\mathbf{N}$ & Medyan & $\begin{array}{l}\text { Ortalama } \\
\text { sıra }\end{array}$ & $\mathbf{P}$ \\
\hline \multirow{5}{*}{$\begin{array}{c}\text { Toplam Fiziksel Aktivite } \\
\text { Puanı }\end{array}$} & Çok zayıf & 9 & 45 & 240,78 & \multirow[t]{5}{*}{,000* } \\
\hline & Zayıf & 13 & 44 & 208,92 & \\
\hline & Normal & 156 & 41 & 180,16 & \\
\hline & $\begin{array}{l}\text { Kilolu veya hafif } \\
\text { şişman }\end{array}$ & 54 & 38 & 117,98 & \\
\hline & Şişman & 68 & 37 & 85,17 & \\
\hline \multirow[t]{5}{*}{ Toplam Uyku Puanı } & Çok zayıf & 9 & 42 & 152,44 & \multirow[t]{5}{*}{0,944} \\
\hline & Zayif & 13 & 42 & 160,73 & \\
\hline & Normal & 156 & 42 & 152,45 & \\
\hline & $\begin{array}{l}\text { Kilolu veya hafif } \\
\text { şişman }\end{array}$ & 54 & 41 & 142,28 & \\
\hline & Şişman & 68 & 42 & 150,34 & \\
\hline \multirow[t]{5}{*}{ Enerji } & Çok zayıf & 9 & 787 & 44,22 & \multirow[t]{5}{*}{, $000^{*}$} \\
\hline & Zayıf & 13 & 837 & 56,69 & \\
\hline & Normal & 156 & 1019 & 112,5 & \\
\hline & $\begin{array}{c}\text { Kilolu veya hafif } \\
\text { şişman }\end{array}$ & 54 & 1224 & 197,93 & \\
\hline & Şişman & 68 & 1364 & 232,01 & \\
\hline
\end{tabular}

Tablo 6. Yaşa göre ağırlık açısından tüketilen karbonhidrat, yağ ve protein miktarları için farkllık analizi

\begin{tabular}{|c|c|c|c|c|c|}
\hline Değişkenler & $\begin{array}{l}\text { Yaşa Göre } \\
\text { Ăğırlık }\end{array}$ & $\mathbf{N}$ & Medyan & $\begin{array}{l}\text { Ortalama } \\
\text { sira }\end{array}$ & $\mathbf{P}$ \\
\hline \multirow[t]{5}{*}{ Karbohidrat } & Çok zayıf & 9 & 100 & 47,22 & \multirow[t]{5}{*}{, $000^{*}$} \\
\hline & Zayif & 1 & 104 & 82 & \\
\hline & Normal & 156 & 126 & 123,25 & \\
\hline & $\begin{array}{c}\text { Kilolu veya hafif } \\
\text { sisman }\end{array}$ & 54 & 145 & 176,5 & \\
\hline & Şişman & 68 & 154 & 219,13 & \\
\hline \multirow[t]{5}{*}{ Yağ } & Çok zayıf & 9 & 25 & 58,61 & \multirow[t]{5}{*}{, $000^{*}$} \\
\hline & Zayif & 13 & 26 & 46,5 & \\
\hline & Normal & 156 & 31 & 112,14 & \\
\hline & $\begin{array}{c}\text { Kilolu veya hafif } \\
\text { şişman }\end{array}$ & 54 & 46 & 196,99 & \\
\hline & Şişman & 68 & 52 & 233,63 & \\
\hline \multirow[t]{5}{*}{ Protein } & Çok zayıf & 9 & 36 & 54 & \multirow[t]{5}{*}{, $000^{*}$} \\
\hline & Zayif & 13 & 43 & 71,04 & \\
\hline & Normal & 156 & 51 & 126,64 & \\
\hline & $\begin{array}{c}\text { Kilolu veya hafif } \\
\text { şişman }\end{array}$ & 54 & 61 & 191,38 & \\
\hline & Şişman & 68 & 60 & 200,74 & \\
\hline
\end{tabular}

Uykunun beslenme üzerine etkisi olduğu gibi, beslenmenin de uyku kalitesi üzerinde etkisi olduğu bilinmektedir. Karbonhidrat $(\mathrm{CHO})$ tüketiminin uyku kalitesi ve uyku süresini etkilediği ve yüksek karbonhidratlı yemeklerin uykululuğu artırdığı tartışılmaktadır (Halson, 2013). Yüksek karbonhidratlı

ve düşük yağlı öğünlerden sonra yavaş dalga uykusunda artış ve REM uykusunda geçirilen sürede azalma olduğu görülmüştür.
Porter ve Horne yaptığı çalışmada 6 erkek bireye yüksek karbonhidratlı (130 g), düşük karbonhidratlı (47 g) ve hiç karbonhidrat içermeyen yemekleri yatmadan $45 \mathrm{dk}$ önce vermiştir. Sonuçlara bakıldığında yüksek karbonhidrat alan grubun REM uykusunda artış olurken, hafif uyku ve uyanıklığın azaldığı bulunmuştur (Porter ve Horne, 1981). Bizim çalışmamızda karbonhidrat alımı ile uyku puanı arasında ilişki incelendiğinde, karbonhidrat ile toplam uyku puanı değişkeni arasında \%13.6 istatistik açısından pozitif yönlü anlamlı ilişki bulunmuş ve karbonhidrat değeri yükseldikçe uyku puanı yükseldiği sonucuna varılmıştır. Bununla birlikte, toplam uyku 
saatlerine baktığımız zaman ise enerjisi yüksek ve karbonhidratı miktarı fazla beslenen çocukların daha az uyuduğu sonucuna varılmıştır. Persentil değerlerinde normal aralıkta olan çocukların büyük kısmının 23:00-00:00 uyuduğu, şişman çocukların ise daha geç uyuduğu sonucuna varılmıştır. Crispim ve arkadaşlarının, 52 katılımcıyla yaptığı çalışmada uyku zamanından 30-60 dakika önce yüksek kalorili ve karbonhidrattan zengin öğün tüketilmesinin uyumada daha geç uymaya sebep olduğunu ortaya çıkarmıştır. Karbonhidrat miktarına ek olarak, glisemik indeksin de uyku düzenleri üzerinde önemli bir etkiye sahip olabileceği fikrini savunulmaktadır (Crispim vd., 2011).

Enerji alımı açısından bakıldığında ise çocukların ortalama gece uykusunda 2 saatlik, 21 dakikalık bir artışın, günlük tüketimden 134 kalori azalmasına, daha düşük leptin seviyeleri ve daha düşük vücut ağırlığı ile sonuçlanmasına sebep olduğu vurgulanmıştır. $\mathrm{Bu}$ bulgular gözlemsel çalışmalarla tutarlı olmakta ve uyku süresinin artması gıda alımının, leptinin ve vücut ağırlığının azaldığını belgelemektedir (Hart vd., 2014). Ulusal Sağlık ve Beslenme Muayene Araştırması'nda, karşılaştırılan gruplarda kisa (5-6 saat) ve uzun ( $>9$ saat) uyku bildiren yetişkinlerde, 7 ila 8 saatlik uyku bildiren grupta daha fazla gıda çeşitliliği ve daha düşük enerji alımı olduğu sonucuna varılmıştır (Grandner, Jackson, Gerstner ve Knutson, 2014). Bizim çalışmamızda çalışmaların sonucunu desteklemektedir ve bu alanda kanıtlanmış fikirleri güçlendirmektedir.

Uyku kalitesini etkileyen ve sağlık için risk oluşturan en önemli faktörlerden biri de fiziksel aktivitenin yeterli olmamasıdır. ABD'de yapılan 2007 Gençlik Riski Davranış Araştırması'nın sonuçlarına göre, ülke genelinde lise öğrencilerinin \% 35'inin okul gününde ortalama 3 saat aktif olduğunu, \% 65'inin ise önerilen fiziksel aktivite miktarlarına ulaşamadığını ortaya çıkarmaktadır (García, Díaz, Rodríguez ve Barroso, 2021). Çocukluk döneminde ise gündüz fiziksel aktivite ve uyku arasındaki ilişkiyi açıklayan kanıtlar yetersizdir. Kanada' da çocuklar üzerinde yapılan çalışma, uyku ve fiziksel aktivite arasındaki ilişkinin güne göre değiştiğini göstermiştir. Fiziksel aktivitenin yoğunluğu, hafta içi ve hafta sonu boyunca önerilen miktarda uyuyanlarda ( $>9$ saat), hafta boyunca düzensiz uyku miktarına sahip olanlara göre daha yüksek olduğu vurgulanmaktadır. Egzersiz, stresi azaltması, kişiyi dışarı çıkarması gibi farklı yollardan da uykuyu güçlendirebilmektedir. Sabah erken ve öğleden sonra yapılan egzersiz, vücut 1sısını biraz arttırarak uyku-uyanıklık döngüsünün sıfırlanmasına ve daha sonraki birkaç saat uykusuzluğa neden olmaktadır (Ryu vd., 2015). Estonyalı ve İsveçli 2.241 genç üzerinde yapılan büyük ölçekli bir çalışma, uyku süresi ile fiziksel aktivite arasında bir bağlantı bulamamıştır (Ekstedt, Nyberg, Ingre, Ekblom ve Marcus, 2013). Bizim çalışmamızda bu sonuçları desteklemekte, uyku ve fiziksel aktivite arasında ilişki bulunmamasıyla sonuçlanmaktadır. Bizim çalışmamızda dahil olmak üzere birçok çalışmalarda, uyku süresi ve uyku kalitesi ölçmek için kendi kendini değerlendiren veya ebeveynlerin bildirdiği uyku anketleri kullanılmaktadır. Tahmini cevaplardan, emin olunmadığında dolayı verilen cevaplar, sonuçların doğruluk payını azaltmaktadır. Çocukluk çağında beslenme ve fiziksel aktivitenin vücut kompozisyonu ve uyku kalitesi üzerinde etkisini incelenen daha fazla çalışmalara ihtiyaç vardır. Katılımcılar için toplam fiziksel aktivite puanı, enerji, karbonhidrat, yă̆ açısından yaşa göre ağırlık grupları arasında anlamlı bir farklılık göstermektedir $(\mathrm{p}<0.05)$. Ortalama sıra değerlerine bakıldığında, fiziksel aktivite puanı çok zayıflarda yüksek, şişman olan çocuklarda daha düşük çıkmıştır. Toplam uyku puanı tüm çocuklarda ortalama aynıdır.
Enerji alımına bakıldığında şişman çocuklarda yüksek, çok zayıf ve zayıf çocuklarda düşüktür. Karbonhidrat, yağ ve protein alımı kilolu, şişman çocuklarda daha yüksek olmaktadır. Toplam uyku puanı ile yaşa göre ağırlık grupları arasında anlamlı bir farklılık yoktur $(\mathrm{p}>0.05)$

\section{Sonuç}

10-12 yaş okul çocuklarında beslenme ve fiziksel aktivitenin vücut kompozisyonu ve uyku kalitesine etkisini incelemeyi hedefleyen araştırma, çocukluk dönemini olumsuz etkileyen faktörleri belirlemek için yapılmıştır. Çalışmalar doğrultusunda beslenmenin önemini vurgulamak çocukluk dönemini geliştirmek için destek olacaktır. Yapılan çalışmalara bakıldığında, tüm risk faktölerine ilave olarak uykunun önemi net bir şekilde anlaşılmıştır.

Son dönemlerde vurgulanan uyku kalitesi ve süresi de sağl1k için önemlidir. Bizim çalışmamızda elde ettiğimiz sonuclara göre, özellikle okulçağı çocuklarında uykunun beslenme, vücut kompozisyonu üzerinde etkileri vardır. Çalışmamızda uykunun her dönem sağlık için tehlike oluşturan obezite ile bağlantısı vurgulanmıştır.

Yapılan çalışmalar doğrultusunda doğru adımlar atılmalı ve doğru hedefler planlanılmalıdır. Beslenmenin öneminde diyetisyen rolü unutulmamalıdır. Çocuklara aileden başlayan doğru beslenme alışkanlıkları kazandırılmalıdır. Erken yaşta kazandırılacak doğru alışkanlıkların, yetişkinlik döneminde sağlığını etkileyebileceği unutulmamalıdır.

Verilecek doğru beslenme ve uyku eğitimleri ile bilinçlendirilmiş ebeveynlerin çocukların sağlığındaki önemi vurgulanmalıdır. Uyku kalitesini ve süresini engelleyecek tüm davranışlar düzeltilmelidir. $\mathrm{Bu}$ bağlamda oluşacak riskleri emgellemek ve önemini daha iyi anlamak için yapılacak çalışmalara ihtiyaç vardır.

\section{Kaynakça}

Verjans-Janssen, S. R., van de Kolk, I., Van Kann, D. H., Kremers, S. P., \& Gerards, S. M. (2018). Effectiveness of school-based physical activity and nutrition interventions with direct parental involvement on children's BMI and energy balancerelated behaviors-A systematic review. PloS one, 13(9), e0204560.

Kim, J., \& Lim, H. (2019). Nutritional management in childhood obesity. Journal of obesity \& metabolic syndrome, 28(4), 225.

Gingras, V., Rifas-Shiman, S. L., Taveras, E. M., Oken, E., \& Hivert, M. F. (2018). Dietary behaviors throughout childhood are associated with adiposity and estimated insulin resistance in early adolescence: a longitudinal study. International Journal of Behavioral Nutrition and Physical Activity, 15(1), 1-12.

Kjeldsen, J. S., Hjorth, M. F., Andersen, R., Michaelsen, K. F., Tetens, I., Astrup, A., ... \& Sjödin, A. (2014). Short sleep duration and large variability in sleep duration are independently associated with dietary risk factors for obesity in Danish school children. International journal of obesity, 38(1), 32-39.

Tolaymat, A., \& Liu, Z. (2017). Sleep disorders in childhood neurological diseases. Children, 4(10), 84.

Crispim, C. A., Zimberg, I. Z., dos Reis, B. G., Diniz, R. M., Tufik, S., \& de Mello, M. T. (2011). Relationship between 
food intake and sleep pattern in healthy individuals. Journal of Clinical Sleep Medicine, 7(6), 659-664.

Morrissey, B., Allender, S., \& Strugnell, C. (2019). Dietary and activity factors influence poor sleep and the sleep-obesity nexus among children. International journal of environmental research and public health, 16(10), 1778.

Harrex, H. A., Skeaff, S. A., Black, K. E., Davison, B. K., Haszard, J. J., Meredith-Jones, K., ... \& Skidmore, P. M. (2018). Sleep timing is associated with diet and physical activity levels in 9-11-year-old children from Dunedin, New Zealand: the PEDALS study. Journal of sleep research, 27(4), e12634.

Hurt, R. T., Frazier, T. H., McClave, S. A., \& Kaplan, L. M. (2011). Obesity epidemic: overview, pathophysiology, and the intensive care unit conundrum. Journal of Parenteral and Enteral Nutrition, 35, 4S-13S.

Han, J. C. (2010). Lawlor D a, Kimm SYS. Childhood obesity2010: progress and challenges. Lancet, 375(9727), 1737-48.

Finn, K. E., Faith, M. S., \& Seo, Y. S. (2018). School engagement in relation to body mass index and school achievement in a high-school age sample. Journal of obesity, 2018.

Alper, Z., Ercan, İ., \& Uncu, Y. (2018). A meta-analysis and an evaluation of trends in obesity prevalence among children and adolescents in Turkey: 1990 through 2015. Journal of clinical research in pediatric endocrinology, 10(1), 59.

Christensen, D. L., Maenner, M. J., Bilder, D., Constantino, J. N., Daniels, J., Durkin, M. S., ... \& Dietz, P. (2019). Prevalence and characteristics of autism spectrum disorder among children aged 4 years - early autism and developmental disabilities monitoring network, seven sites, United States, 2010, 2012, and 2014. MMWR Surveillance Summaries, 68(2), 1 .

Zhang, N., \& Ma, G. (2018). Childhood obesity in China: trends, risk factors, policies and actions. Global Health Journal, 2(1), $1-13$.

Ricotti, R., Caputo, M., Monzani, A., Pigni, S., Antoniotti, V., Bellone, S., \& Prodam, F. (2021). Breakfast Skipping, Weight, Cardiometabolic Risk, and Nutrition Quality in Children and Adolescents: A Systematic Review of Randomized Controlled and Intervention Longitudinal Trials. Nutrients, 13(10), 3331.

Feye, D., Gobena, T., Brewis, A., \& Roba, K. T. (2021). Adolescent Breakfast Skipping Is Associated With Poorer Academic Performance: a School-based Study From Hidhabu Abote District, Ethiopia.

Kartal, F. T., Burnaz, N. A., Yaşar, B., Sağlam, S., \& Kıymaz, M. (2019). Adölesanların Beslenme Bilgi Düzeylerinin Beslenme ve Egzersiz Alışkanlıkları Üzerine Etkisinin İncelenmesi. CBÜ Beden Eğitimi ve Spor Bilimleri Dergisi, 14(2), 280-295.

Akman, M., Tüzün, S., \& Ünalan, P. C. (2012). Adolesanlarda Sağlıklı Beslenme Ve Fiziksel Aktivite Durumu. Nobel Medicus Journal, 8(1).

Ambrosini, G. L., Emmett, P. M., Northstone, K., \& Jebb, S. A. (2014). Tracking a dietary pattern associated with increased adiposity in childhood and adolescence. Obesity, 22(2), 458465.

Gingras, V., Hivert, M. F., \& Oken, E. (2018). Early-life exposures and risk of diabetes mellitus and obesity. Current diabetes reports, $18(10), 1-10$.

Barbaros, H., \& Balcı, S. (2016). Küreselleşen Dünyada Çocuklarda Büyüyen Sorun: Obezite The Growing Problem Of Children İn Globalized World: Obesity Barbaros, H.*
Balcı S. Yıldırım Beyazıt Üniversitesi Hemşirelik E-Dergisi, $3(2)$.

Oliveira, L. C., Ferrari, G. L. D. M., Araújo, T. L., \& Matsudo, V. (2017). Overweight, obesity, steps, and moderate to vigorous physical activity in children. Revista de saude publica, 51.

Michalopoulou, M., Gourgoulis, V., Kourtessis, T., Kambas, A., Dimitrou, M., \& Gretziou, H. (2011). Step counts and body mass index among 9-14 years old greek schoolchildren. Journal of sports science \& medicine, 10(1), 215.

Yan-Ping, L. I., Xiao-Qi, H. U., Schouten, E. G., Ai-Ling, L. I. U., Song-Ming, D. U., Lin-Zhong, L. I., ... \& Guan-Sheng, M. A. (2010). Report on childhood obesity in China (8): effects and sustainability of physical activity intervention on body composition of Chinese youth. Biomedical and Environmental Sciences, 23(3), 180-187.

Keskin, K., Çubuk, A., Alpkaya, U., \& Öztürk, Y. (2017). 12-14 Yaş Çocukların Fiziksel Aktivite Düzeyleri ile Beslenme Davranışları Arasındaki İlişkinin İcelenmesi. İstanbul Üniversitesi Spor Bilimleri Dergisi, 7(3), 34-43.

Den Wittenboer, V. (2000). Time in bed, quality of sleep and school functioning of children. Journal of sleep research, 9(2), 145-153.

Fisher, A., McDonald, L., van Jaarsveld, C. H. M., Llewellyn, C., Fildes, A., Schrempft, S., \& Wardle, J. (2014). Sleep and energy intake in early childhood. International journal of obesity, 38(7), 926-929.

Sekine, M., Yamagami, T., Handa, K., Saito, T., Nanri, S., Kawaminami, K., ... \& Kagamimori, S. (2002). A doseresponse relationship between short sleeping hours and childhood obesity: results of the Toyama Birth Cohort Study. Child: care, health and development, 28(2), 163-170.

Halson, S. L. (2013). Nutritional interventions to enhance sleep. Sports Science Exchange, 26(116), 1-5.

Porter, J. M., \& Horne, J. A. (1981). Bed-time food supplements and sleep: effects of different carbohydrate levels. Electroencephalography and clinical neurophysiology, 51(4), 426-433.

Hart, C. N., Carskadon, M. A., Considine, R. V., Fava, J. L., Lawton, J., Raynor, H. A., ... \& Wing, R. (2013). Changes in children's sleep duration on food intake, weight, and leptin. Pediatrics, 132(6), e1473-e1480.

Grandner, M. A., Jackson, N., Gerstner, J. R., \& Knutson, K. L. (2014). Sleep symptoms associated with intake of specific dietary nutrients. Journal of sleep research, 23(1), 22-34.

García, P. J. C., Díaz, A. L., Rodríguez, J. G., \& Barroso, J. G. (2021). Exploring food and physical activities between grandparents and their grandchildren. Explorando comidas y actividades físicas entre abuelos y sus nietos. Anuario de Psicología/The UB Journal of Psychology, 51(2).

Ryu, J. Y., Lee, J. S., Hong, H. C., Choi, H. Y., Yoo, H. J., Seo, J. A., ... \& Choi, K. M. (2015). Association between body size phenotype and sleep duration: Korean National Health and Nutrition Examination Survey $\mathrm{V}$ (KNHANES V). Metabolism, 64(3), 460-466.

Ekstedt, M., Nyberg, G., Ingre, M., Ekblom, Ö., \& Marcus, C. (2013). Sleep, physical activity and BMI in six to ten-yearold children measured by accelerometry: a cross-sectional study. International Journal of Behavioral Nutrition and Physical Activity, 10(1), 1-10. 